\title{
PENGAPLIKASIAN PANEL SURYA PADA MOBIL LISTRIK
}

\author{
Rusuminto Syahyuniar \\ Jurusan Mesin Otomotif Politeknik Negeri Tanah Laut \\ E-mail: rusumintosyahyuniar@yahoo.com
}

\begin{abstract}
ABSTRAK
Perubahan sumber energi matahari dengan memanfaatkan panel surya menjadi sumber energi listrik yang terbarukan merupakan upaya untuk mengurangi konsumsi bahan bakar fosil, panel surya memiliki kelebihan yaitu mampu mengurangi polusi dan hemat energi jika diaplikasikan pada mobil listrik. Penelitian ini bertujuan untuk mendapatkan hasil pengukuran arus dan tegangan dari panel surya serta baterai sebagai sumber listrik untuk pengisian tenaga pada panel surya. Sistem panel surya mencakup 4 panel surya $50 \mathrm{Wp}, 1$ battray charge unit, 4 baterai 35 Ah, dan 1 motor listrik yang terpasang dalam mobil listrik. Dari penelitian yang dilakukan perancangan panel surya pada mobil listrik dengan kemiringan $45^{\circ}$ agar nantinya panel surya mendapat cahaya matahari yang lebih besar. Maka dapat diperoleh hasil yaitu pengukuran dari pukul 07:00 - 17:00 dan nilai output panel surya \pm 60.00 Volt dan Arus \pm 23.00 A (fluktuasi nilai tegangan dan arus akan berubah berdasarkan waktu, cuaca dan lingkungan sekitar) sehingga daya yang dihasilkan pada $\pm 10720,1$ Watt, lama waktu pemakaian beban dari motor litrik daya yang dihasilakan dibagi dengan beban mobil listrik 10720,1 watt / 1680 watt maka akan mendapat 6,4 jam pemakaian mobil listrik.
\end{abstract}

Kata kunci : baterai, suhu, arus dan tegangan, pengisian baterai, panel surya.

\section{PENDAHULUAN}

Dalam era globalisasi ini, teknologi sangat berkembang pesat di masyarakat. Keefektifan dalam mengelola atau memanajemen pada kehidupan manusia secara langsung maupun tidak langsung dituntut untuk selalu bertindak efisien dalam beraktivitas dan menemukan sebuah inovasi terbaru untuk menunjang kehidupannya. Salah satunya untuk menghadapi masalah sumber daya alam yang makin berkurang,

Belakangan ini semakin banyak yang mencoba mengembangkan mobil tenaga listrik. Hal itu disebabkan karena persediaan material utama minyak bumi yang cadangannya mulai menipis, sehingga harus ada jalan keluar untuk mengatasi hal tersebut dengan cara mencari energi alternatif dengan memanfaatkan energi surya dan listrik yang di aplikasikan ke dalam mobil. Namun mobil tenaga listrik masih belum efektif karena apabila isi dari baterai mobil tersebut habis maka mobil tersebut harus berhenti dan harus melakukan mengisian ulang, dan jika ingin memakai mobil listrik dengan jarak atau waktu yang lama dibutuhkan baterai yang banyak pula sehingga kurang efektifnya penggunaan dari mobil listrik tersebutbotol ini juga diharapkan dapat memenuhi kebutuhan bahan bakar di masa depan.

Untuk mengatasi permasalahan tersebut maka diperlukan beberapa inovasi misalnya dengan pemasangan solar sel untuk sistem pengisisan pada baterai diperlukan sebagai power pada penggerak dari motor listrik tersebut maka di dalam penelitian ini peneliti melakukan modifikasi mobil dengan cara menambahkan sel surya, pemasangan sel surya pada mobil listrik agar baterai dimobil listrik tidak terkuras habis. Oleh karena itu pada sistem pengisian Sel surya diaplikasikan sebuah alat konversi energi yang mengubah bentuk energi surya menjadi energi listrik. Energi yang dihasilkan oleh sel surya adalah energi yang paling ramah lingkungan, namun lahan instalasi yang diperlukan sangat luas. Selain itu, energi surya sangat tergantung pada besarnya intensitas sinar matahari, sehingga kontinuitasnya menjadi masalah tersendiri. Pemanfaatan energi surya ini dipilih karena di Indonesia merupakan negara tropis yang berada di jalur khatulistiwa. Didalam memanfaatkan energi surya ini penyusun mencoba untuk menggunakan proses fotovoltaik, yaitu dengan cara mengkonversikan secara langsung energi surya menjadi energi listrik. (I Gusti Ngurah Nitya Santhiarsa: 2008).

Penempatan sel surya yang ringan selain berfungsi untuk mengisi ulang baterai juga tidak menambah beban dari laju mobil tersebut. Dengan pemasangan sel surya maka kinerja mobil listrik menjadi lebih efektif, mobil tenaga listrik dapat terus berjalan meskipun tempat pengisian ulang arus dan tegangan pada baterai disuatu daerah tidak ada. Sebab mobil listrik yang sudah ada harus berhenti dulu untuk mengisi ulang baterai apabila kapasitas dari baterai tersebut habis. Berdasarkan latar belakang tersebut maka penulis berinisiatif untuk penambahan sel surya terhadap mobil listrik disini agar semakin berkembang mobil listrik dan mengatasi masalah terkikisnya atau semakin habisnya bahan utama dari bahan bakar. Selain itu juga dapat mengurangi polusi udara yang semakin banyak di bumi ini. 
Rumusan masalah dari kegiatan ini adalah:

1. Bagaimana merancang pemasangan panel surya pada mobil listrik.

2. Bagaimana cara kerja panel surya pada mobil listrik untuk mengetahui keluaran panel surya, arus, tegangan dan daya.

Sedangkan tujuannya adalah:

1. Merancang pemasangan panel surya pada mobil litrik.

2. Untuk mengetahui cara kerja panel surya pada mobil listrik.

Untuk mengetahui arus, tegangan dan daya pada panel surya.

\section{METODOLOGI}

\section{Studi Literatur}

Langkah pertama yang dilakukan sebelum melakukan penelitian adalah studi literature. Studi literatur adalah mengumpulkan penelitian yang terdahulu yang terbarukan, kemudian merumuskan permasalahan yang ada dan mencari solusi dengan mengumpulkan literatur penelitian terbarukan serta teori yang terkait dengan permasalahan yang ada.

Dalam tahap studi literature ini dikumpulkan penelitian yang telah dilakukan dan dasar-dasar teori yang terkait dengan topik pemanfaatan sel surya, dan mekanisme sel surya, baik dari jurnal, artikel, texk book, handbook dan lain-lain.

\section{Identifikasi Masalah}

Setelah melakukan studi litelatur, masalah yang dapat diindetifikasi adalah jika sel surya dipasang dimobil listrik diberi input sinar matahari, maka akan dihasilkan output berapa energi listrik dalam bentuk. Cahaya matahari menyinari panel surya diserap oleh panel surya maka akan mengahasilkan energi listrik akan mengalir ke Battery charge unit lalu ke aki.

\section{Persiapan Alat dan Bahan}

1. Adapun jenis peralatan yang digunakan pada penelitian ini dapat dilihat dibawah ini:

A. Mesin las / Travo las listrik sebanyak 1 unit.

B. Gerinda tangan sebanyak 1 unit.

C. Meteran sebanyak 1 unit.

D. Mistar siku sebanyak 1 unit.

E. Mesin bor dan mata bor sebanyak 1 unit.

F. Sepidol permanen sebanyak 1 buah.

2. Adapun jenis bahan yang digunakan pada penelitian ini dapat dilihat dibawah ini :
A. Panel surya Polycrystalline
B. Battery charger unit
C. Battery
D. Multimeter
E. Pengukur suhu
F. Mata gerinda amplas kasar sebanyak 1 pcs
G. Mata gerinda potong sebanyak 1 pcs
H. Elektroda RD sebanyak 1 pcs
I. Besi siku sebanyak 1 batang

\section{Lokasi dan Objek Penelitian}

Penelitiaan ini akan dilaksanakan pada bulan Mei sampai Juli 2016 di Politeknik Negeri Tanah Laut dan Lapangan Pertasi Kabupaten Tanah Laut.

\section{Instrumen Penelitian}

Perangkat penelitian yang digunakan :
A. Panel Surya.
B. Baterai / Accu.
C. Battery Charge Unit (BCU).
D. Multi meter.
E. Pengukur suhu.

\section{Perancangan Model}

Untuk merancang model dalam penelitian ini disesuaikan dengan tujuan penelitian dimana sebuah sistem teknologi photovoltaic yang sederhana adalah tersusun dari sel photovoltaic yang dihubungkan dengan charge controller yang berfungsi untuk menstabilkan arus tegangan yang keluar dari panel surya sebelum diteruskan ke dalam baterai atau accu sebagai penyimpan arus. Disebabkan tegangan yang dikeluarkan oleh panel surya dan baterai adalah tegangan DC (Direct Current) dan tegangan pada motor litrik DC (Direct Current) 48 Volt maka memerlukan baterai atau accu sebanyak 4 buah yang di seri.

\section{Perakitan}

Dalam perakitan panel surya dimobil listrik dapat dilihat dibawah ini :

1. Potong besi siku dan pasang ke panal surya, satu buah panel surya empat buah siku, siku ini untuk menahan dari getaran saat berkendara dijalan.

Pasang panel surya tiga buah di atas mobil

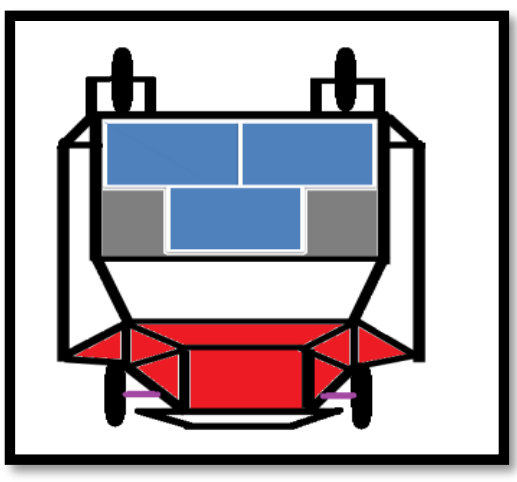

Gambar 1 Perakitan Panel Surya Pada Mobil Listrik

pengukuran suhu dengan cara memakai alat pengukur suhu dengan mengukur suhu di lokas modul surya setiap 1 jam sekali, semua data yang diambil kemudian di catat dan kemudian nanti akan diolah.

\section{Data yang Diperlukan}

Untuk menganalisa sistem ini diperlukan beberapa data sebagai berikut:

1. Spesifikasi photovoltaic. 
2. Daya keluaran dari 3 buah photovoltaic yang berupa tegangan dan arus DC.

3. Nilai suhu udara lingkungan pada saat pengujian dengan satuan derajat selcius.

\section{Diagram Alir Penelitian}

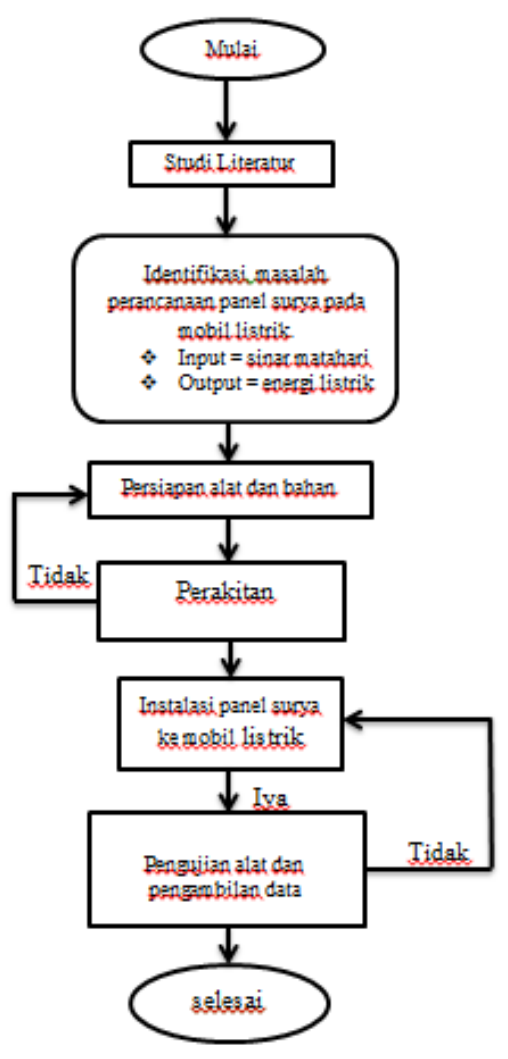

\section{Instalasi Panel Surya Ke Mobil Listrik}

Adapun perakitan panel surya ini dapat dilihat dibawah ini :

1. Pasang kabel ke 3 buah panel surya secara serie untuk mendapat ampare dari panel surya.

2. Sambungkan kabel yang sudah di serie di panels surya ke battery chager unit.

3. Pasang kabel batarai atau accu yang sudah di serie ke battery chager unit.

4. Pasang kabel baterai atau accu yang di seri ke motor listrik.

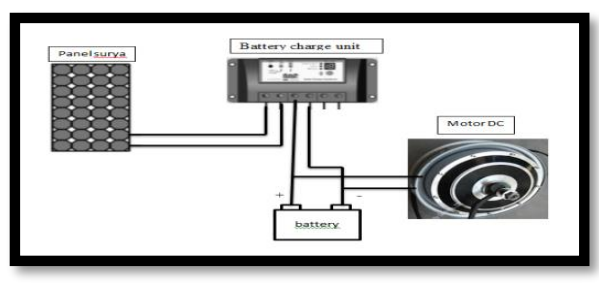

Gambar 2 Rangkaian Instalasi Panel Surya Untuk Mobil Listrik

\section{Pengujian Alat dan Pengumpulan Data}

Pengujian alat dan pengambilan data primer dilakukan secara langsung di lapangan berupa pengambilan sampel baik itu tegangan arus dan suhu, Pengambilan data arus dan tegangan dilakukan dengan menggunakan alat ukur atau multi meter digital. Pengukuran arus dan tegangan dilakukan pada saat mobil listrik dijalankan. Kemudian untuk

\section{HASIL DAN PEMBAHASAN}

\section{Perancangan Panel Surya Pada Mobil Listrik}

Dalam pemasang panel surya pada mobil listrik, hal yang harus dilihat adalah cahaya atau intesitas radiasi matahari bisa mengenai panel surya agar panel surya bekerja secara maksimal untuk medapatkan tegangan dan arus. Dalam perancangan panel surya pada mobil listrik, panel surya dibuat miring $45^{\circ}$ supaya panel surya dapat menyerap cahaya pada matahari secara maksimal dikarenakan cahaya matahari tepat pada titik diatas panel surya.

Langkah pertama dalam pembuatan rangka agar menyatu dengan bagian atap mobil. besi siku dengan ukuran $100 \mathrm{~cm}$ pada 2 buah panel surya, pasang baut dengan ukuran $10 \mathrm{~mm}$ pada besi siku dan panel surya yang telah dibor, setalah terpasang kencangkan baut agar besi siku dan panel surya tidak terlepas. Supaya bagian depan dan belakang panel surya tersambung pasang besi plat yang telah dipotong dengan ukuran panjang $10 \mathrm{~cm}$ dan lebar $5 \mathrm{~cm}$ pasang besi plat kebagian tengah panel surya, bagian besi plat ditengah panel surya berfungsi sebagai penyambung ke tiga buah panel surya dan juga kemiringan sama dengan bagian belakang.

Setelah ke tiga buah panel surya tepasang diatap mobil listrik, di bagian belakang panel surya dibuat miring supaya mempermudah pemasangan panel surya dan panel surya dapat menyerap cahaya walaupun pada saat membelakangi matahari. Bagian panel surya Las duah buah besi plat yang sudah dipotong dengan ukuran panjang $8 \mathrm{~cm}$ dan lebar $4 \mathrm{~cm}$, fungsi sebagai penahan beban panel surya agar tidak terjatuh atau pun terlepas dari bagian tengah panel surya.

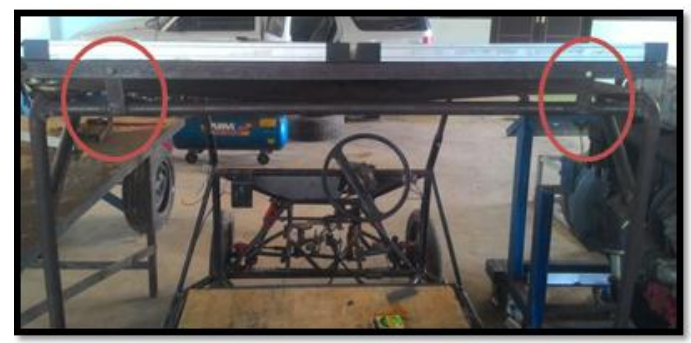

Gambar 3 Pemasangan panel surya bagian belakang 


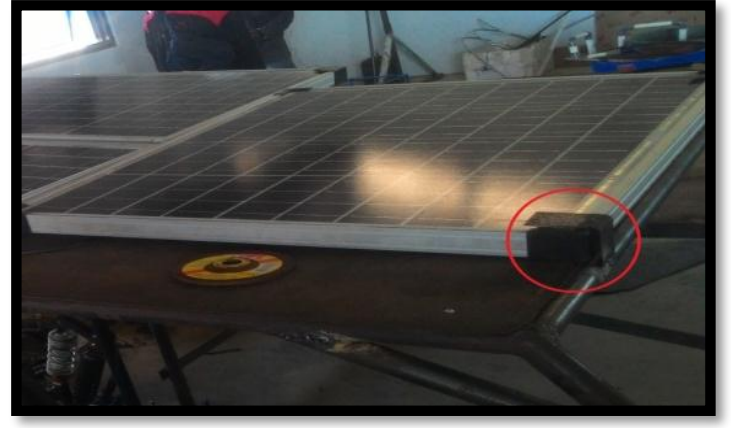

Gambar 4 Pemasangan Panel Surya Bagian Depan

\section{Instalasi Panel surya Pada Mobil Listrik}

Dalam pemasangan kabel dari panel surya untuk mengisi empat buah baterai dengan tegangan 48 volt dan arus 35 ampere, maka panel surya memerlukan tegangan yang besar untuk mengisi baterai pada mobil listrik. Langkah pertama dalam instalasi panel surya, sambungkan kabel dari tiga buah panel surya dalam rangkaian seri, fungsi dari rangkaian seri ini untuk mendapatkan tegangan yang besar tanpa mengubah arus tersebut. Ditakutkan pada saat pengisian baterai arus dari baterai akan kembali dan merusak komponen panel surya, maka dari itu sebelum panel surya mengalirkan arus ke baterai, terlebih dahulu menuju battery charge unit, fungsi dari battery charge unit agar melindungi baterai dari pengisisan berlibihan dan melindungi pengiriman arus keinput terminar yang berlebihan. Setelah kabel terpasang pada battery charge unit, sambungkan kabel dari battery charge unit pada baterai biarkan untuk mengisi pada pagi sampai dengan sore hari, dikarenakan pengisian menggunakan panel surya memerlukan waktu yang lama dan tidak sebentar.

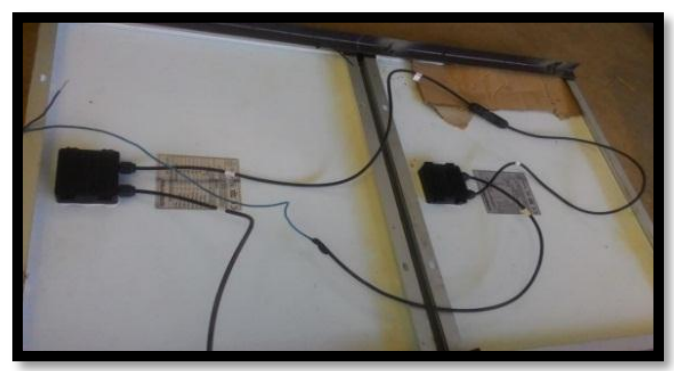

Gambar 5 Pemasangan Kabel Pada Panel Surya

\section{Data Pembacaan Suhu}

Untuk mengetahui suhu pada panel surya, memerlukan pengukur suhu agar mengetahui keluaran panel surya dengan mendeteksi suhu sesuai interval pengukuran tersebut, dalam penelitian ini ingin mengetahui berapa keluaran panel surya berdasarkan suhu pada panel surya tersebut, adapun data yang dapat berbentuk tabel dan grafik sebagai berikut:
Tabel 1 Perbandingan Waktu dan Suhu Luar

\begin{tabular}{|l|c|c|c|}
\hline NO & Tanggal & jam & $\begin{array}{c}\text { Suhu permukaan } \\
\text { panel surya }{ }^{\circ} \mathrm{C}\end{array}$ \\
\hline 1 & $19 / 08 / 2016$ & 07.00 & 24 \\
\hline 2 & $19 / 08 / 2016$ & 08.00 & 28,5 \\
\hline 3 & $19 / 08 / 2016$ & 09.00 & 35,5 \\
\hline 4 & $19 / 08 / 2016$ & 10.00 & 38,4 \\
\hline 5 & $19 / 08 / 2016$ & 11.00 & 39 \\
\hline 6 & $19 / 08 / 2016$ & 12.00 & 41,3 \\
\hline 7 & $19 / 08 / 2016$ & 13.00 & 39 \\
\hline
\end{tabular}

\begin{tabular}{|l|c|c|c|}
\hline 8 & $19 / 08 / 2016$ & 14.00 & 38,4 \\
\hline 9 & $19 / 08 / 2016$ & 15.00 & 36,3 \\
\hline 10 & $19 / 08 / 2016$ & 16.00 & 34,6 \\
\hline 11 & $19 / 08 / 2016$ & 17.00 & 30,6 \\
\hline 12 & $20 / 08 / 2016$ & 07.00 & 23,7 \\
\hline 13 & $20 / 08 / 2016$ & 08.00 & 25 \\
\hline 14 & $20 / 08 / 2016$ & 09.00 & 31 \\
\hline 15 & $20 / 08 / 2016$ & 10.00 & 35,5 \\
\hline 16 & $20 / 08 / 2016$ & 11.00 & 37,2 \\
\hline 17 & $20 / 08 / 2016$ & 12.00 & 39,4 \\
\hline 18 & $20 / 08 / 2016$ & 13.00 & 37,8 \\
\hline 19 & $20 / 08 / 2016$ & 14.00 & 37,4 \\
\hline 20 & $20 / 08 / 2016$ & 15.00 & 36,4 \\
\hline 21 & $20 / 08 / 2016$ & 16.00 & 34,2 \\
\hline 22 & $20 / 08 / 2016$ & 17.00 & 28,7 \\
\hline 23 & $21 / 08 / 2016$ & 07.00 & 28 \\
\hline 24 & $21 / 08 / 2016$ & 08.00 & 31 \\
\hline 25 & $21 / 08 / 2016$ & 09.00 & 37,8 \\
\hline 26 & $21 / 08 / 2016$ & 10.00 & 38 \\
\hline 27 & $21 / 08 / 2016$ & 11.00 & 39 \\
\hline 28 & $21 / 08 / 2016$ & 12.00 & 42,3 \\
\hline 29 & $21 / 08 / 2016$ & 13.00 & 43,5 \\
\hline 30 & $21 / 08 / 2016$ & 14.00 & 40 \\
\hline 31 & $21 / 08 / 2016$ & 15.00 & 38,3 \\
\hline 32 & $21 / 08 / 2016$ & 16.00 & 36,3 \\
\hline 33 & $21 / 08 / 2016$ & 17.00 & 35,8 \\
\hline & & & \\
\hline
\end{tabular}

Berikut ini Gambar 6, grafik perbandingan waktu dengan suhu panel surya data yang diambil, dari data dilihat bahwa pada tanggal 19 Agustus 2016 suhu pada panel surya terbilang normal dikarenakan suhu tidak menurun secara signifikan, pencahaayaan yang cukup untuk panel surya. Pada jam 12.00 sampai jam 14.00 suhu mengalami penurunan 1 derajat selcius, suhu menurun dikarenakan kelembaban pada kecepana angina sehingga angina medinginkan panel surya tapi tidak mengurangi suplay listrik ke aki.

Pada suhu tanggal 20 Agustus 2016 berbanding terbalik pada hari sebelumnya yaitu suhu mengalami penurunan yang cukup drastis, dikarenakan sinar matahari menuju panel surya tertutup awan yang menyebabkan pencahayaan pada panel surya kurang maksimal. Pada tanggal 12.00 sampai 14.00 yang seharusnya cahaya matahari berada ditengah-tengah panel surya yang mencapai suhu berada 40 derajat celcius tapi ini dibawah 40 derajat selcius suplay listrik ke aki mengalami penurunan.

Sedang pada tanggal 21 Agustus 2016 suhu pada panel surya mengalami peningkatan dari dua hari sebelumnya, yaitu pada jam 12.00 sampai 14.00 saat sinar matahari tepat menyinari di atas panel surya dan pencahayaan yang maksimal, suhu pada panel surya mencapai $40-43.5^{\circ} \mathrm{C}$, maka akan membuat suplay listrik 
ke aki maksimal. Pada pagi hari suhu menurun dikarenakan matahari baru terbit dan pada sore hari suhu juga mengalami penurunan dikarenakan matahari terbenam, intensitas cahaya ke panel surya kurang maksimal.

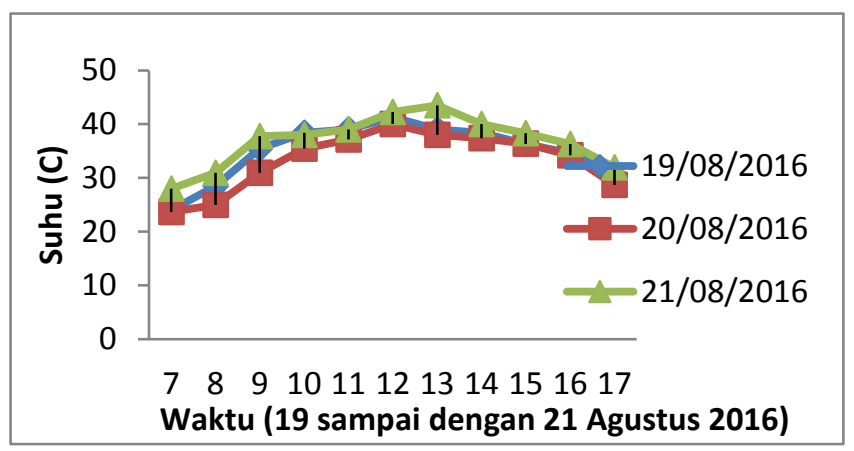

Gambar 6 Grafik perbandingan waktu dengan suhu

\section{Pengolahan Data}

Pada pengambilan data pengeluan panel surya berupa tegangan dan arus, maka memerlukan sebuah alat yang bias mengetahui berapa tegangan dan berapa besarnya arus. Multi meter merupakan merupan alat yang bisa mengetahui besaran tegangan dan arus. Berikut tabel dan grafik pada pengambilan data mengunakan multi meter :

Tabel 2 Hasil Pengukuran Pv Terhadap Arus dan Tegangan

\begin{tabular}{|c|c|c|c|c|}
\hline Tanggal & Jam & $\begin{array}{c}\text { Tegangan } \\
\text { (volt) }\end{array}$ & $\begin{array}{c}\text { Arus } \\
\text { (Ampere) }\end{array}$ & $\begin{array}{c}\text { Daya } \\
\text { (watt) }\end{array}$ \\
\hline $19 / 08 / 2016$ & 07.00 & 51,7 & 5 & 258,5 \\
\hline $19 / 08 / 2016$ & 08.00 & 59,9 & 6,5 & 389,3 \\
\hline $19 / 08 / 2016$ & 09.00 & 61,2 & 14 & 856,8 \\
\hline $19 / 08 / 2016$ & 10.00 & 61,4 & 20 & 1228 \\
\hline $19 / 08 / 2016$ & 11.00 & 61,5 & 23 & 1414,5 \\
\hline $19 / 08 / 2016$ & 12.00 & 61,5 & 25 & 1537,5 \\
\hline $19 / 08 / 2016$ & 13.00 & 61,9 & 23,6 & 1460,8 \\
\hline $19 / 08 / 2016$ & 14.00 & 62,2 & 21,7 & 1349,7 \\
\hline $19 / 08 / 2016$ & 15.00 & 61,5 & 17,5 & 1076,2 \\
\hline $19 / 08 / 2016$ & 16.00 & 61,4 & 11,1 & 681,5 \\
\hline $19 / 08 / 2016$ & 17.00 & 48,7 & 9,6 & 467,5 \\
\hline $20 / 08 / / 2016$ & 07.00 & 49,3 & 3 & 147,9 \\
\hline $20 / 08 / / 2016$ & 08.00 & 53,4 & 5,5 & 293,7 \\
\hline $20 / 08 / / 2016$ & 09.00 & 58,3 & 10,2 & 600,5 \\
\hline $20 / 08 / / 2016$ & 10.00 & 59,1 & 14 & 827,4 \\
\hline $20 / 08 / / 2016$ & 11.00 & 60,7 & 23,8 & 1444,7 \\
\hline $20 / 08 / / 2016$ & 12.00 & 61 & 23,8 & 1451,8 \\
\hline $20 / 08 / / 2016$ & 13.00 & 60,5 & 21 & 1270,5 \\
\hline $20 / 08 / / 2016$ & 14.00 & 60,5 & 20 & 1210 \\
\hline $20 / 08 / / 2016$ & 15.00 & 59,8 & 16 & 956,8 \\
\hline $20 / 08 / / 2016$ & 16.00 & 59,7 & 13 & 776,1 \\
\hline $20 / 08 / / 2016$ & 17.00 & 56,2 & 8,4 & 472,1 \\
\hline $21 / 08 / 2016$ & 07.00 & 55,5 & 6 & 333 \\
\hline & & & & \\
\hline
\end{tabular}

\begin{tabular}{|c|c|c|c|c|}
\hline $21 / 08 / 2016$ & 08.00 & 58 & 10 & 580 \\
\hline $21 / 08 / 2016$ & 09.00 & 61,2 & 18 & 1101 \\
\hline $21 / 08 / 2016$ & 10.00 & 62,6 & 20 & 1252 \\
\hline $21 / 08 / 2016$ & 11.00 & 63,5 & 21,7 & 1377,9 \\
\hline $21 / 08 / 2016$ & 12.00 & 62,5 & 25 & 1562,5 \\
\hline $21 / 08 / 2016$ & 13.00 & 62,5 & 27,2 & 1700 \\
\hline $21 / 08 / 2016$ & 14.00 & 62 & 23,2 & 1438,4 \\
\hline $21 / 08 / 2016$ & 15.00 & 62 & 20,7 & 1283,4 \\
\hline $21 / 08 / 2016$ & 16.00 & 62 & 16,7 & 1035,4 \\
\hline $21 / 08 / 2016$ & 17.00 & 60 & 14,2 & 852 \\
\hline
\end{tabular}

Proses pengolahan data dilakukan dari pagi sampai dengan sore hari. Yaitu Pengukuran dengan menggunakan multi meter untuk mengetahui keluaran panel surya yang berupa tegangan dan arus. selama tiga hari penelitian. dari Tabel 1 tentang perbandingan suhu dan waktu, bandingkan dengan Tabel 2 hasil pengukuran, bahwa suhu mempengaruhi tegangan dan arus pada panel surya. Tapi yang paling berpengaruh pada suhu panel surya berupa arus. Jika suhu di permukaan panel surya meningkat arus pada panel surya meningkat jika suhu pda panel surya menurun arus keluaran panel surya menurun juga, Berikut adalah cara mengetahui mendapatkan daya pada panel surya.

Pada pukul 07.00 tegangan 51.7 volt dan arusnya 5 ampere, maka untuk memerlukan daya listrik bisa dihitung dengan rumus sebagai berikut :

$$
\mathrm{P}=\mathrm{V} . \mathrm{I}
$$

$\mathrm{P}=51,7$ volt $\mathrm{x} 5$ ampere $=258,5 \mathrm{watt}$

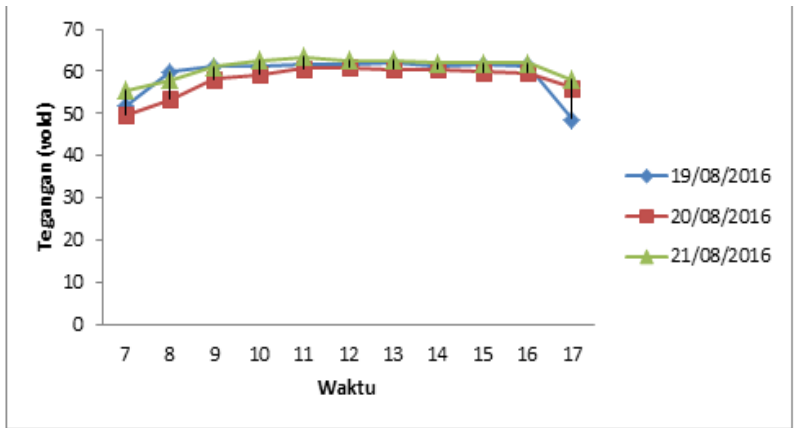

Gambar 7 Grafik pengukuran tegangan di sistem.

Sedangkan Gambar 7, grafiknya memperlihatkan data tegangan yang dihasilkan oleh sel surya dibandingkan dengan waktu, dari data yang terlihat bahwa nilai pada tanggal 19 Agustus 2016 keadaan normal tidak mengalami penurunan drastis pada keluaran panel surya, dibandingkan pada tanggal 20 Agustus 2016 mengalami penurunan dibandingkan hari kemarin. Suhu tertinggi pda jam 12.00 dan menurun pada jam selanjutnya.

Pada tanggal 21 Agustus 2016 tegangan meningkat pada dua hari sebelumnya yaitu mencapai 62,5 volt. Pada tabel 4.1 perbandingan suhu, nilai tegangan tidak begitu berpengaruh terhadap suhu permukaan panel surya hanya berkurang 1 sampai 5 volt. Tegangan pada pagi dan sore menurun di karenakan panel surya kurang 
menyerap cahaya matahari.berikut grafik perbandingan tegangan dengan waktu :

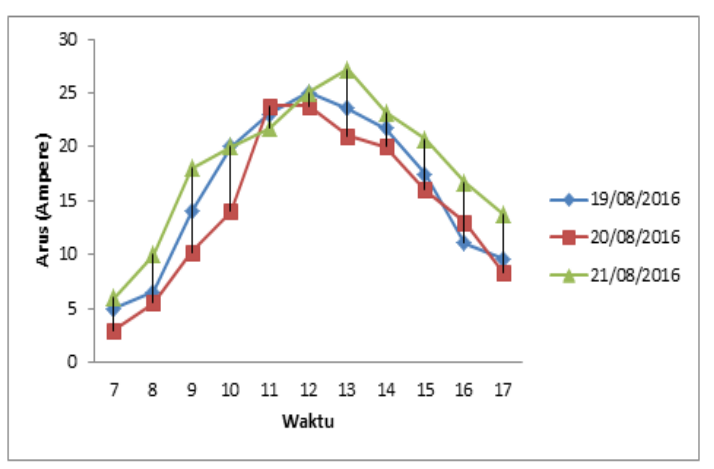

Gambar 8 Grafik Pengukuran Perbandingan Waktu dengan Arus

Pada Gambar 8, memperlihatkan grafik perbandingan arus dengan waktu dan pada Tabel 1 perbandingan suhu dengan waktu, bahwa naik atau turunnya suhu pada panel surya berpengaruh besar pada arus. dari Gambar 8 dan Tabel 1 selama tiga hari penelitian suhu menurun pada pagi hari arus ikut menurun dan meningkat pada siang hari arus ikut meningkat ketika sore suhu menurun kembali. disebabkan pada rangkain panel surya dirangkai seri jadi mencari tegangan pada panel surya, berikut perbandingan arus dengan waktu :

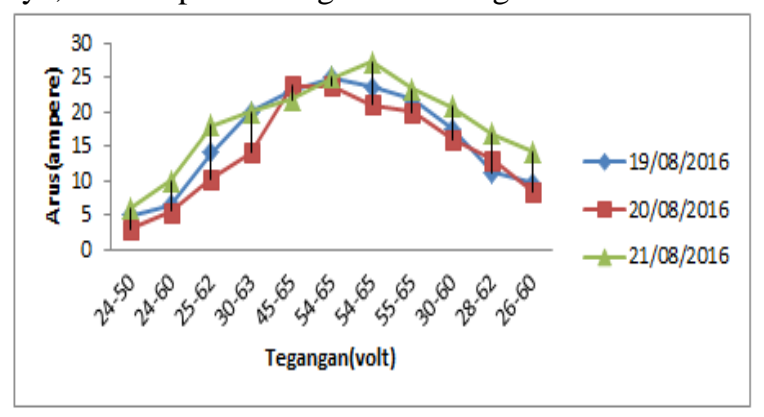

Gambar 9 Grafik Tegangan dan Arus

Sedangkan Gambar 9 ini memperlihatkan data perbandingan antara arus dan tegangan yang dihasilkan oleh sel surya dibandingkan dengan waktu.

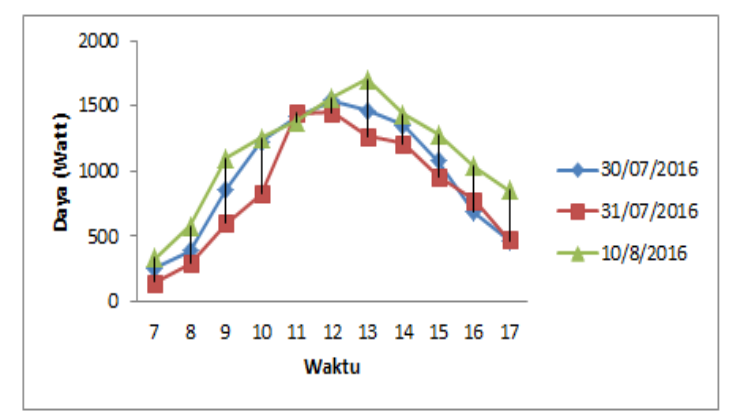

Gambar 10 Grafik waktu dan daya

Dari Gambar 10 dapat dilihat bahwa daya paling bawah pengambilan data ini adalah pada jam 07.00 dimana matahari baru terbit, sedangkan daya paling tinggi pada sekitaran jam 12.00 sampai 14.00 dimana posisi yang cukup cerah dan berada diposisi tengah hari, jadi dapat dikatakan penyerapan energi matahari cukup bagus, sedangkan pada sore hari mengalami penurunan dikarenakan matahari pada posisi terbenan dan panel surya kurang menyerap sinar matahari.

Kondisi yang perlu diperhatikan juga saat rangkaian PV ini terhubung dengan beban dimana supply PV akan langsung menuju beban setelah distabilkan melewati charger controller jika supply PV ke beban lebih besar dari pada kebutuhan beban itu sendiri maka sisa suplly akan dialirkan ke supply ke beban semetara PV akan terhubung ke baterai dengan mem-supply baterai saat kapasitas beterai pada titik rendah. Ketika baterai dalam keadaan penuh BCU akan menutupi hubungan antara PV dan baterai sehingga tegangan keluaran PV tidak lagi mengisi baterai hal ini untuk menghindari kerusakan dari baterai.

\section{Perhitungan teknis \\ Perhitungan lama pemakaian pada mobil listrik}

Daya yang dikeluarkan oleh panel surya maksimum dengan besaran wattpeak (wp), seberapa besar intensitas cahaya matahari yang mengenai permukaan panel. Dimana panel surya pada penelitian ini berkapasitas $50 \mathrm{Wp}$ kemudian dilihat dari nilai rata-rata perhari keadaan cuaca kampus Politeknik Negeri Tanah Laut disinari matahari dengan tertinggi pada jam 12.00 sampai 14.00 WITA dengan daya 1700 watt. Daya sebesar ini akan mensupllay ke motor listrik dengan tegangan 48 volt dan arus 35 ampere.

Untuk megetahui daya motor listrik = volt motor x kapasitas motor Dikarenakan untuk mengetahui sebuah motor listrik untuk bejalan kita memerlukan berapa volt dan berapa ampere.

$$
\begin{aligned}
& \text { Daya pada motor listrik } \\
& =48 \text { volt } x 35 \text { ampere } \\
& =1.680 \text { watt }
\end{aligned}
$$

Jadi untuk menjalankan sebuah motor listrik kita memerlukan tegangan 48 volt, arus 35 ampere dan daya sebesar kurang lebih 1.680 watt. Untuk mengetahui energi yang diserap oleh baterai dari panel surya kita ambil dari table 4.2 pada tanggal 19 Agustus 2016 dengan menjumlahkan seluruh energi yang diserap oleh baterai sebagai berikut:

Total energy

$$
\begin{aligned}
& =\sum(p \cdot t) \\
& =258,5 w h+389,3 w h+856,8 w h+ \\
& 1228 w h+1414,5 w h+1537,5 w h+ \\
& 1460,8 w h+1349,7 w h+1076,2 w h+ \\
& 681,5 w h+467,5 w h \\
& =10720,1 w h
\end{aligned}
$$

Sedangkan untuk mengetahui lama waktu pemakaian beban dari motor litrik, maka kita akan melakukan analisa dari beban motor listrik dengan energy yang di simpan di baterai, adapun rumusnya sebagai berikut:

$$
\begin{array}{ll}
\mathrm{W} & =\mathrm{P} \cdot \mathrm{t} \\
\mathrm{t} & =\mathrm{W} / \mathrm{P}
\end{array}
$$




$$
\begin{aligned}
\mathrm{t} & =10720.1 \mathrm{wh} / 1680 \mathrm{~W} \\
& =6,4 \text { jam }
\end{aligned}
$$

Dari hasil perhitungan diatas maka alat ini dapat jalan selama 6,4 jam, sehingga selama dalam pejalanan mobil listrik akan hidup 6,4 jam dalam kondisi normal

\section{Perhitungan pada panel surya}

Intesitas sinar matahari sangan berpengaruh pada panel surya, jika intesita panel surya kurang maka keluaran panle surya juga berkurang dan sebaliknya. Adapun rumus sebagai berikut:

$\mathrm{E}=\operatorname{Ir} \times \mathrm{A}$

Dimana

$$
\begin{aligned}
\text { Ir } & =\text { intesitas radiasi matahari rata-rata }\left(\mathrm{w} / \mathrm{m}^{2}\right) \\
& =114,91 \mathrm{w} / \mathrm{m}^{2} \\
\mathrm{~A} & =\text { Luas penampang }\left(\mathrm{m}^{2}\right) \\
\mathrm{A} & =\mathrm{P} \times \mathrm{L}
\end{aligned}
$$

Dimana luas penampang masing-masing panel surya :

$$
\begin{aligned}
& =\text { panjang }(\mathrm{m}) \\
& =\text { lebar }(\mathrm{m})
\end{aligned}
$$

Luas penampang

A1 = panjang $6,8 \mathrm{~m} \times$ luas $5,4 \mathrm{~m}$

$\mathrm{A} 2=$ panjang $6,8 \mathrm{~m} \times$ luas $5,4 \mathrm{~m}$

$\mathrm{A} 3=$ panjang $6,8 \mathrm{~m} \times$ luas $5,4 \mathrm{~m}$

$\mathrm{A} 4=$ panjang $6,8 \mathrm{~m} \times$ luas $5,4 \mathrm{~m}$

Total luas penampang :

$$
\begin{aligned}
\mathrm{At} & =\mathrm{A} 1+\mathrm{A} 2+\mathrm{A} 3+\mathrm{A} 4 \\
\mathrm{At} & =36,72 \mathrm{~m}+36,72 \mathrm{~m}+36,72 \mathrm{~m}+36,72 \mathrm{~m} \\
& =146,88 \mathrm{~m}^{2}
\end{aligned}
$$

Maka energi yang diterima oleh panel surya sebagai berikut :

$$
\begin{aligned}
\mathrm{E} & =\operatorname{Ir} \times A \\
& =114,91\left(\mathrm{w} / \mathrm{m}^{2}\right) \times 146,88 \mathrm{~m}^{2} \\
& =16.878 \mathrm{~W}
\end{aligned}
$$

Untuk menghitung daya rata-rata pada panel surya pada tanggal 19 sampai dengan 21 Agustus 2016 yang dibutuhkan :

$$
\begin{aligned}
& \mathrm{P}=\mathrm{V} \times \mathrm{I} \\
& \text { Dimna: } \\
& \begin{aligned}
\mathrm{P} & =\text { daya rata-rata }(\mathrm{w}) \\
& =\mathrm{P} 1+\mathrm{P} 2+\mathrm{P} 2 \\
& =974,5+859,2+1.137,8 \\
& =2.971,5
\end{aligned}
\end{aligned}
$$

Untuk mendapatkan nilai rata-rata arus pada panel surya sebagai berikut:

$$
\begin{aligned}
\mathrm{I} & =\mathrm{I} 1+\mathrm{I} 2+\mathrm{I} 3 \\
& =16+14,4+18.4 \\
& =48,8 \mathrm{~A}
\end{aligned}
$$

Maka akan dapat beda potensial pada panel surya sebagai berikut:

$$
\begin{aligned}
\mathrm{V} & =\mathrm{P} / \mathrm{I} \\
& =2.971,5 / 48,8 \\
& =60,9 \text { volt }
\end{aligned}
$$

Efesiansi panel surya merupan perbandingan daya yanag dapat dibandingkan oleh panel surya dengan energi input yang diperoleh dari sinar matahari, maka akan didapat nilai efesiensi pada panel surya sebagai berikut:

$$
\begin{aligned}
\text { Nsc } & =\mathrm{P} / \mathrm{E} \times 100 \% \\
& =2.971,5 / 16.878 \times 100 \% \\
& =17,60 \%
\end{aligned}
$$

Nilai yang dihasilkan dari 4 panel surya sebesar 17,60\%

\section{Perhitungan deklenasi dan sudut matahari}

Deklenasi dan sudut matahari dengan bidang equator akan berubah akibat kemiringan bumi dari +23 $45^{\circ}$ pada musim panas yaitu bulan pada tanggal 21 juni dan $-23-45^{\circ}$ dimusim dingin yaitu pada tanggal 21 desember. Data yanga diambil pada bulan juni sampai sampaidengan agustus deklenasinya $\delta=+23.45^{\circ}$ sehingga harga atau nilai deklenari.

Dimana $\mathrm{n}=$ hari dari tahunyang bersangkutan, maka pada tanggal 1 agustus $n=275$ hari, maka kan didapat dengan rumus: $\delta=23.45 \sin \left(360 \times \frac{284+275}{365}\right)$

$$
\begin{aligned}
& =23,45 \sin 442.8 \\
& =4.155^{\circ}
\end{aligned}
$$

Untuk mengetahui sudut zenith maka akan didapat

$(\theta Z)=\sin \delta \sin \emptyset+\cos \delta+\cos \omega$

Dimana:

$\varnothing=$ tempat / lokasi kabupaten Tanah Laut

$=3,15$

$\omega=$ sudut jam optimal $15^{\circ}-20^{\circ}$

$$
=15^{\circ}
$$

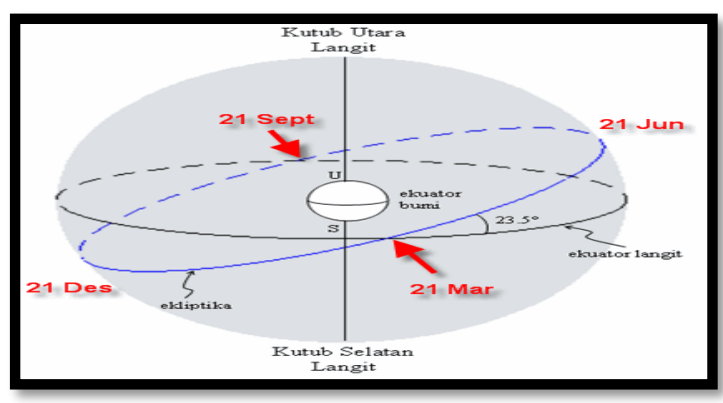

Gambar 11 Posisi Matahari Pada Bidang Equator (sumber: $B M K G, 2016$ )

Maka pada tanggal 1 Agustus

$$
\begin{aligned}
\operatorname{Cos} \theta Z & =\sin \delta \sin \emptyset+\cos \delta+\cos \omega \\
& =\sin 4.16 \sin 3.15+\cos 4.16 \cos 3.15 \cos 15 \\
& =0,622
\end{aligned}
$$$$
\theta \mathrm{Z}=51.54^{\circ}
$$

Untuk mengetahui sudut ketinggian

$$
\propto=90^{\circ}-51.54^{\circ}
$$

$$
=38.49^{\circ}
$$

$$
\begin{aligned}
\operatorname{Cos} \theta \mathrm{A} & =\frac{\sin \delta-\sin \emptyset \cos \emptyset Z}{\cos \emptyset \sin \emptyset Z} \\
\operatorname{Cos} \theta \mathrm{A} & =\frac{\sin 4.16-\sin 3.15 \cos 51.54}{\cos 3.15 \sin 51.54} \\
& =\frac{(0,065)-(0,05)(0,568)}{(0,999)(0,823)} \\
& =0,045 \\
& =87.42^{\circ}
\end{aligned}
$$

Untuk harga IbT dimna B diambil $15^{\circ}$ 


$$
\begin{aligned}
& \operatorname{IbT}=\operatorname{Ir} \frac{\sin \delta(\varnothing-B)+\cos \delta+\cos \delta \cos (\varnothing-B)}{\sin \delta \sin \emptyset+\cos \delta \cos \emptyset \cos \omega} \\
&=114.91 \frac{\sin 4.16\left(3.15-15^{\circ}\right)+\cos 3.15+\cos 4.16 \cos \left(4.16-15^{\circ}\right) \cos 15^{\circ}}{\sin 4.16 \sin 3.15+\cos 4.16 \cos 3.15 \cos 15^{\circ}} \\
&=111.25 \mathrm{w} / \mathrm{m}^{2}
\end{aligned}
$$

Radiasi matahari sebaran dan pantulan, maka radiasi sebaran diambil sudut $15^{\circ}$ jadi.

$$
\operatorname{IdT}=\operatorname{Id}\left(\frac{1.0+\cos \beta}{2}\right)
$$

Dimana:

$\mathrm{Id}=$ besaran radiasi sebaran perjam pada permukaan horizontal diambil rata-rata 8,6 lang ley

$$
=360.125 \mathrm{w} / \mathrm{m}^{2}
$$

Maka:

$$
\begin{aligned}
\operatorname{IdT} & =360.125\left(\frac{1.0+\cos 15}{2}\right) \\
& =355.15 \mathrm{w} / \mathrm{m}^{2}
\end{aligned}
$$

Radiasi pantulan (IrT) diambil sudut $15^{\circ}$

$\operatorname{IrT}=\propto(\operatorname{Ir}+\operatorname{Id})\left(\frac{1.0+\cos \beta}{2}\right)$

Dimana:

$\propto=$ reflektansi diambil $0,21-0,25$ untuk permukaan tanpa sudut sehingga:

$$
\begin{aligned}
\operatorname{IrT} & =0,23(114.91+360.125)\left(\frac{1.0+\cos 15}{2}\right) \\
& =109.26\left(\frac{1.0+\cos 15}{2}\right) \\
& =107.75 \mathrm{w} / \mathrm{m}^{2}
\end{aligned}
$$

Sehingga untuk total intesitas radiasi matahari (Ir)

$$
\begin{aligned}
\mathrm{Ir} & =\mathrm{IbT}+\mathrm{IdT}+\mathrm{IrT} \\
& =111.25+335.15+107.75 \\
& =574.15 \mathrm{w} / \mathrm{m}^{2}
\end{aligned}
$$

Maka daya yang dihasilkan pada panel surya, sebagai berikut:

$$
\begin{aligned}
\mathrm{A} & =\text { luas penampang } \\
\mathrm{Nsc} & =\text { efesiansi solar cell } \\
& =0,35 \% \\
\mathrm{Fr} & =\text { factor koleksi } \\
& =0,7
\end{aligned}
$$

Maka akan didapatkan:

$=$ A . Ir . nsc . Fr

$=110,16 \times 114,91 \times 0,35 \% \times 0,7$

$=31.01 \mathrm{w}$

Maka daya yang didapat dari perhitungan ini adalah 31.01 watt.

\section{KESIMPULAN}

Berdasarkan analisa data dari pemanfaatan solar sel pada mobil listrik sebagai energi alternatif, maka dapat disimpulkan sebagai berikut:

1. Dalam perancangan pemasangan panel surya pada mobil listrik, panel surya diletakan diatas kap mobil listrik dan dibuat miring $45^{\circ}$ agar mempermudah pemasangan dan dapat maksimal menyerap cahaya matahari pada pagi hari sampai sore hari.
2. Cara kerja panel surya pada mobil listrik, cahaya dari matahari diserap oleh panel surya dan menjadi energi listrik. energi listrik yang dihasilkan panel surya dapat mengisi baterai pada mobil listrik.

3. untuk menjalankan sebuah motor listrik kita maka diperlukan tegangan 48 volt, arus 35 ampere dan daya sebesar kurang lebih 1.680 watt. Pada tangaal 19 Agustus 2016 dengan menjumlahkan seluruh daya yang diserap sebesar 10720,1 wh. Maka dibagi dengan beban pada motor listrik sebesar 1.680 watt maka alat ini dapat berjalan selama 6,4 jam, sehingga selama dalam pejalanan mobil listrik akan hidup 6,4 jam dalam kondisi normal.

\section{SARAN}

Pada pembuatan panel surya pada mobil listrik ini ada beberapa saran yang dapat dikemukakan untuk kesempurnaan dan pengembangan masa mendatang antara lain:

1. Pada keadaan yang sebenarnya, sebaiknya menggunakan panel surya yang berukuran besar dan mempunyai arus yang lebih besar, sehingga kemampuannya untuk menerima cahaya matahari lebih baik.

2. Sebelum mengoprasikan mobil listrik sebaiknya mobil listrik di charger satu hari sebelum pemakian atau mengoprasikan pada jam 12.00 sampai dengan 14.00 dikarenakan pada waktu itu tegangan dan arus lebih maksimal.

\section{DAFTAR PUSTAKA}

[1] Andri., Z. 2009. Prototipe Listrik Dengan Menggunakan Motor DC magnet Permanen 0,37 HP.

[2] Boxwell., Michael. 2012. Solar ElectricityHand book

[3] Mayfield.,Ryan .2014. Photo Volteic Design \& Instalation for Dummies.

[4] Bradford., travis.2008 solar Revolution

[5] Helmi, M., 2009. Pemanfaatan Energi Matahasi Menggunakan Solar Cell Sebagai Energi Alternatif untuk Menggerakkan Konveyor. Tugas Akhir. Politeknik. www.solardaya.com diakses pada tanggal 15 Maret 2016.

[6] Purwadi., A. 20014. Penelitian dan Pengembangan Mobil Listrik Nasional.

[7] Mutaqien,. Idzani., 2012 rancang bangun hybrid turbin angin dan panel surya 